\title{
Self-Disclosure and Moroccan EFL Learners' Writing Development: Effects on Complexity, Accuracy, and Fluency
}

\author{
Mohsine Jebbour \\ Moulay Ismail University \\ Correspondence concerning this article should be addressed to Mohsine Jebbour, ENCG/ SCALEC Research \\ Laboratory, Moulay Ismaïl University, Présidence, Marjane 2, BP: 298, Meknès, Morocco, 50000. \\ E-mail: m.jebbour@umi.ac.ma
}

\begin{abstract}
This article addressed the relationship between students' self-disclosure-that is, sharing social and positive information-and writing development in the English language classroom. The pretest-post-test research design was adopted to assess whether students' reflections on personal positive experiences including feelings and opinions help improve their writing output as measured by complexity, accuracy, and fluency. The participants, drawn from a convenience sample, were 15 Moroccan students enrolled in the department of English studies at a Moroccan university. These participants were included to establish a homogenous level of English proficiency in writing. The participants completed a pre-test, six positive self-disclosure topics, and a post-test. A pairedsample t-test was computed to determine if a significant mean difference existed between the pre- and post-tests. Although the descriptive statistics suggest that the learners showed relative improvement in complex and fluent language, their overall writing development did not reach a statistically significant difference level. Although differing writing prompts and learners' academic learning experiences influenced the overall findings, this study contributes to the debate about the role of self-disclosure activities in improving certain language components in writing and calls for developing study programs that consider students' personal lives in language arts classes.
\end{abstract}

Keywords: CAF measures, EFL students, self-disclosure, positivity, writing development

\section{Introduction}

In departments of English studies in Morocco, many courses require students to show their work through writing, a widely used vehicle for these learners to practice and enhance language skills in the English as a foreign language (EFL) context (Birhan, 2018; McDonough \& Fuentes, 2015). Hence, this study considers writing that involves students' production of complex, accurate, and fluent language (see Norris \& Manchón, 2012).

Students' reflections on personal disclosures-including feelings, opinions, and experiences-are anchored to language learning theory, particularly second language (L2) motivation, language teaching methodology, and writing pedagogy (for more information, see Jebbour, 2020). This inclusion supports this study's objective to consider the relationship between self-disclosure and language development in writing.

Reflecting on self-disclosures can support learners' writing performances, in that writing about personal information fosters engagement in the task, increases the proportion of topic-relevant main clauses, allows students to pay close attention to language form, and provides access to well-known information (Bento, 1991; Dörnyei, 1994; Foster \& Skehan, 1996; Guilloteaux \& Dörnyei, 2008; Skehan \& Foster, 1997). Consequently, students become familiar with the content of the target task, particularly the level of sentence structures, vocabulary, and grammatical rules. Assumably, "as students incorporate this understanding and awareness into their own writing, their writing performance, particularly the complexity [, accuracy] and fluency of their essays, will also improve" (Barrot, 2018, p. 188).

\section{Aims and Significance of the Study}

This study explores whether students' reflections on personal disclosure contribute to their writing development in university-level EFL classrooms. Specifically, this investigation aimed to determine whether 
undergraduate EFL learners' reflections on personal positive experiences including feelings and opinions aid writing development in terms of three research questions:

1. Does reflecting on positive self-disclosure help improve EFL learners' production of complex language in writing?

2. Does reflecting on positive self-disclosure help improve EFL learners' production of accurate language in writing?

3. Does reflecting on positive self-disclosure help improve EFL learners' production of fluent language in writing?

Results from this study will inspire language educators, including university teachers of English who consider writing a venue for language development. The results will also increase these teachers' understanding of the role of personal tasks in language arts classes.

\section{Literature Review}

\section{Classroom Self-Disclosure}

Self-disclosure was first a subject of research in interpersonal relationships in humanist psychology and subsequently in communication studies. In psychology, self-disclosure refers to "the act of revealing personal information to others" (Jourard, 1971, p. 2), where sharing personal information with people is an underlying criterion of a healthy personality. In communication studies, self-disclosure means "any message about the self that a person communicates to another" (Wheeless \& Grotz, 1976, p. 338).

Students' personal disclosure in the classroom is highly affected by others' responses. If responses are positive and supportive, students will feel safe to self-disclose (Wakefield, 2009). However, a negative reaction, particularly from teachers and classmates, may cause students not to reveal their personal disclosures (Berman, 2001; Derlega et al., 2010).

Students may share different topics when engaging in self-disclosure. Specifically, social penetration theory (SPT) posits that individuals may communicate superficial, social, and/or intimate information to others. Superficial information involves sharing biographical information such as names, hometown, and hobbies. Social information pertains to disclosing opinions, feelings, experiences, attitudes, etc.; and intimate information emerges when the discloser deeply shares private secrets, such as family problems (Altman \& Taylor, 1973; Cayanus \& Martin, 2016; Derlega et al., 2008).

Students' self-disclosures can take different dimensions: relevance, negativity, and positivity (Cayanus \& Martin, 2016). Relevance occurs when disclosing information relating to the course content, like sharing an experience of doing voluntary work when discussing community service (Jebbour, 2018; Jebbour \& Mouaid, 2019). Negativity involves sharing 'bad' information in the classroom like lying to teachers, whereas positivity entails disclosing desirable aspects of one's life like getting an 'A' in class (Cayanus et al., 2009).

Although different topics and dimensions govern the process of self-disclosure, the operational definition chosen for inclusion in this study is self-disclosure, which involves students' communication of social and positive information in writing. It is essential to note that sharing intimate disclosures is socially undesirable and inappropriate in the classroom setting and is likely to deteriorate the professional aspect of the teacher-student relationship (Lannuti \& Straumann, 2006; Myers, 1998; Zhang et al., 2009). Hence, this study supports the sharing of social information in the classroom. Examples of such social information include personal feelings, opinions, and experiences (Guilloteaux \& Dörnyei, 2008). In addition, because self-disclosing desirable information helps foster interpersonal relationships (see West \& Turner, 2010), this justifies considering the positivity dimension in this research. The implication is that students' sharing of personal positive information in the writing classroom may help them establish a healthy relationship with the reader (i.e., classmates and/or teachers).

The use of self-disclosure activities in writing is grounded in the expressive/process movement in English language pedagogy. This approach considers writing to be a means for self-discovery, thereby giving students 
an opportunity to express their personal feelings through journal writing and narratives (see Lam, 2015; Reid, 2001), which facilitate revision as an essential component of the writing process (Stotsky, 1995). Tasks involving self-disclosure may also function as a learning practice (Moon, 2004), inasmuch as students have "opportunities to explore [their] own lives and to discover things about themselves and others that they may not otherwise have learnt" (Stotsky, 1995, p. 758). Finally, expressing self-disclosures allows students to enhance reflective thinking (Hoadley-Maidment, 2000), in that personal writing "can be among the most intellectually rigorous genres, demanding self-discipline and self-criticism” (Berman, 2001, p. 7).

\section{Complexity, Accuracy, and Fluency in Writing}

Complexity, accuracy, and fluency (CAF) measures are considered essential components of language performance in writing (see Norris \& Manchón, 2012). Experts in the field of L2 acquisition have devoted close attention to the study of the dimensions of CAF to understand language performance (see Wolfe-Quintero et al., 1998; Barrot \& Gabinete, 2019).Yet, researchers use different parameters to observe the development of the three CAF measures in learners' spoken and written language. Thus, considering the different parameters of the CAF measures is relevant.

First, complexity refers to the use of varied and elaborated lexical and syntactic structures (Barrot \& Gabinete, 2019). Previous research used parameters, such as word frequency, sentence length (Peng \& Wang, 2018), simple, compound, complex, and compound-complex sentence types, subordination/coordination, word per finite-verb, and complex noun structures to measure linguistic and syntactic complexity (Rosmawati, 2014).

Second, accuracy involves the ability to produce error-free language in writing (Barrot \& Gabinete, 2019) and is measured by different parameters, including holistic scales, error-free units, and the number of errors with/ without classification (see Polio \& Shea, 2014). These measures have a degree of reliability and validity, and each measure is used depending on the purpose of the study. For instance, holistic scales measuring accuracy in terms of vocabulary, spelling, punctuation, syntax, idiom use, etc. are usually used for placement purposes (Polio, 2001).

Third, fluency involves the "ability to produce written words and other structural units in a given time" (Barrot \& Gabinete, 2019, p. 2). That is, the more a language learner is fluent, the faster he/she can retrieve vocabulary and linguistic chunks to construct a written text. The literature on this parameter indicates that fluency in L2 writing is measured from the product or process perspectives or both. When looking at writing as product, measures, composition scholars count the number of words, clauses, and T-units produced in a final text (Larson-Freeman, 2006; Polio, 2001). However, when examining L2 writing through a process lens, researchers consider other measures, including the mean number of characters, mean number of characters during rewriting, mean pause time length between words, and standard deviation of characters (Van Waes \& Leijten, 2015).

CAF measures are "dimensions for describing language performance, most frequently used as dependent variables to assess variation with respect to independent variables such as acquisition level or task features" (Palloti, 2009, p. 590). Therefore, the type of task that teachers assign in the writing class affects students' content of writing, their degree of engagement in the production process, and the learning outcomes achieved in the end (Norris \& Manchón, 2012). Tasks involving self-disclosures play a crucial role in increasing language students' interest and engagement in the learning process (Dörnyei, 1994; Guilloteaux \& Dörnyei, 2008; Stotsky, 1995). This is well attested by the fact that Personalised Language Use - that is, writing about self-disclosure - was found to increase motivation to use the foreign language (Bernard, 2010) and guarantee meaningful language learning (Iida, 2016), which are essential for interlanguage development (Skehan \& Foster, 1997).

Research exploring the impact of self-disclosure tasks on students' language development in the language arts classroom remains sparse in the currently available literature. Writing about self-disclosures in a computermediated communication environment increases learning autonomy and improves students' writing in English (Serag, 2011). Specifically, when students talk about personal information, they produce a larger amount of accurate output (Foster \& Skehan, 1996; Skehan \& Foster, 1997). In addition, when students write about personal experiences, they tend to produce lengthy pieces of writing with accurate sentences and suitable diction (Komalasari, 2013). Such insights are a point of departure to explore whether reflecting on positive selfdisclosures is a vehicle through which learners can develop their language skills by producing complex, accurate, and fluent language in writing. 


\section{Materials and Methods}

\section{Research Design}

A number of studies on L2 writing development used cross-sectional research designs without having control groups (see Polio \& Park, 2016). This study adopted the same methodological approach to test if university students' reflections on their positive self-disclosures aided writing development in terms of CAF in the EFL classroom. Data were collected and coded using a quantitative approach and submitted to statistical analyses to answer the three research questions formulated at the onset of this study.

\section{Assessments and Measures}

The measures adopted to assess writing development in the participants' pre- and post-tests were complexity: counting the number of clauses per T-unit $(\mathrm{C} / \mathrm{T})-\mathrm{a}$ T-unit refers to an independent clause and its dependent clauses (Barrot \& Gabinete, 2019, p. 4)-, accuracy: counting the number of error-free T-units per T-unit (EFT/T), and fluency: calculating the number of words per T-unit (W/T). These CAF measures served as a tool to assess the participants' writing performance before participating in this study.

\section{Participants}

This study was limited to undergraduate students from the department of English studies at a Moroccan university. Upon receipt of the approval from the graduate office in charge of research activities at the university, the researcher recruited 19 participants who were willing to take part in this study because self-disclosure is considered a voluntary activity (Antaki et al., 2005).

The 19 participants completed a writing activity before they were officially included in the study. The results indicated that 15 participants' writing output showed no statistically significant difference in the production of C/T, $F(2,12)=.19, p=.82$, EFT/T, $F(2,12)=.78, p=.48$, and $\mathrm{W} / \mathrm{T}, F(2,12)=.93, p=.42$. Based on this result, these 15 students ( 7 males and 8 females), with ages from 19 to 25 years, were recruited. As for their education level, five were first-year students, five were second-year students, and five were third-year students.

The anonymity of the participants was guaranteed by giving each student a code (e.g., Participant 1, Participant 2, etc.). To ensure confidentiality, the participants' names are not mentioned throughout the manuscript.

\section{Instrumentation}

This study employed a pre-test-post-test instrument to assess whether the EFL students' reflections on their positive self-disclosures aided the development of CAF in their writing output (i.e., pre-test and post-test). Prior to collecting actual data from the participants, the researcher, in consultation with a university professor of English with more than 30 years of teaching experience, developed eight writing prompts (six self-disclosure topics, a pre-test, and a post-test).

Four of the eight writing prompts were given to five undergraduate students of English. Three participants expressed unfamiliarity with the topics, which resulted in developing new writing prompts that were again distributed to the same students, who finally affirmed familiarity with the topics. Given that familiarity reduces working memory demands (Klingberg, 2010) and enhances students' writing performance (Graham et al., 2015), this justified the validity of the writing prompts.

\section{Materials}

Participants responded to the following prompts:

\section{Pre-test}

In one coherent paragraph, tell the reader about your favourite movie, book, or short story, and why people should watch it or read it. 


\section{Post-test}

The university should organise a visit to the United States or England for students of English as a part of their learning experience. Do you agree or disagree? Explain your answer and use examples to support your opinions.

\section{Self-Disclosure Writing Prompts}

1) Write one coherent paragraph in which you define the characteristics of a positive friendship. Explain who your best friend is and express your feelings about him/her. 2) Write one coherent paragraph in which you recount a positive learning experience at university. Describe the experience and give your opinions and feelings about it. 3) In some countries, young adults have jobs while they are still students. Do you think this is a good idea? Support your opinion by using specific reasons and examples. 4) Write one coherent paragraph in which you define the characteristics of a good teacher. Tell the reader who your best teacher is and express your feelings about him/her. 5) Write a coherent paragraph in which you tell the reader about an exciting travel experience you have had alone or with a friend or family member. Specify the time and place and your feelings about the experience. 6) People go to university for different reasons (for instance, to expand their knowledge, to be important people in society, etc.). According to your experience as a student, tell the reader positive reasons for going to university. Use specific reasons and examples to support your answer.

\section{Procedure}

Initially, the participants completed the writing pre-test. After collecting the pre-test scripts, the participants completed six writing topics that elicited their positive personal disclosures. Next, the researcher distributed the writing post-test after the completion of the self-disclosure topics. The participants received no feedback on their writing performance throughout the study. Overall, the students had one week to complete each writing activity. They completed the writing prompts outside the classroom because attendance is not mandatory at the university, and the participants had different schedules. Such circumstances required giving the participants enough time to complete the writing tasks at their convenience. Hence, the writing prompts were collected on different days each week because meeting the participants at the same time was elusive. The participants' writing output was coded after ensuring that they did not deviate from the purpose of each writing task.

\section{Coding}

The data were coded for the three CAF measures. For the complexity construct, the total numbers of clauses (C) were divided by the total numbers of T-units ( $\mathrm{T}$ ) to obtain $\mathrm{C} / \mathrm{T}$. As for accuracy, the total numbers of error-free T-units (EFT) were divided by the total numbers of T-units (T) to have EFT/T. Regarding fluency, the total numbers of words (W) were divided by the total numbers of T-units (T) to obtain W/T. Table 1 summarises the coding scheme used in this study.

Table 1

Calculation of CAF measures

\begin{tabular}{lll}
\hline \multicolumn{1}{c}{ Component } & \multicolumn{1}{c}{ Code } & \multicolumn{1}{c}{ Calculation } \\
\hline Complexity & $\mathrm{C} / \mathrm{T}$ & Clauses per T-unit \\
Accuracy & $\mathrm{EFT} / \mathrm{T}$ & Error-free T-units per T-unit \\
Fluency & $\mathrm{W} / \mathrm{T}$ & Words per T-unit \\
\hline
\end{tabular}

The participants' means and standard deviations in the three CAF measures in the pre-test were as follows: $\mathrm{C} / \mathrm{T}: M=3.73, S D=1.63$, EFT/T: $M=.37, S D=.20$, W/T: $M=19.75, S D=3.95$. Their means and standard deviations in the post-test were as follows: $\mathrm{C} / \mathrm{T}: M=4.06, S D=1.56$, EFT/T: $M=.31, S D=.32$, W/T: $M=23.06, S D=7.68$.

\section{Inter-Rater Reliability}

The pre-test and post-test texts (a writing post-test sample is provided in Appendix A) were submitted to three raters. The author was rater 1. Rater 2 was a university professor of English with more than 15 years of experience in teaching. Rater 3 was a university professor of English who had more than 30 years of teaching experience. The raters employed the three parameters (i.e., C/T, EFT/T, and W/T) for tracking CAF measures 
to analyse the participants' writing output (the analysis of the writing post-test sample is provided in Appendix B). A meeting was held between the author and each of the raters to discuss the accuracy of the coding.

Percent agreement between raters was employed to measure reliability. The rationale for using the percentage of overlapping positive cases was that it is considered a relatively better measure of reliability since it yields the cases confirmed by the raters (Rosmwati, 2014). In the current research, the percent agreement reached $90 \%$ for complexity (C/T), $76 \%$ for accuracy (EFT/T), and $88 \%$ for fluency (W/T). Such results are considered consistent and trustworthy (van Geert \& van Dijk, 2003).

\section{Data Analysis}

A paired-sample $t$-test was conducted to analyse the data gathered from the participants; $p<.10$ was required for significance as the recommended set alpha in L2 research (see Larson-Hall, 2010). Specifically, three pairedsample $t$-tests were computed to explore if a significant mean difference existed between the participants' preand post-tests in an effort to provide empirical evidence supporting whether the EFL students' reflections on their positive self-disclosures aided the development of CAF in their writing output.

\section{Results}

\section{Descriptive Statistics}

The participants' mean scores on CAF measures, shown in Figure 1, indicated improvement in the production of $\mathrm{C} / \mathrm{T}$ and $\mathrm{W} / \mathrm{T}$ and a breakdown in the production of EFT/T. Over the eight-week period of this study, the EFL students' writing performance was more complex and fluent but less accurate after completing the six selfdisclosure prompts.

\section{Figure 1}

The participants' mean scores on CAF measures in the pre-and post-tests
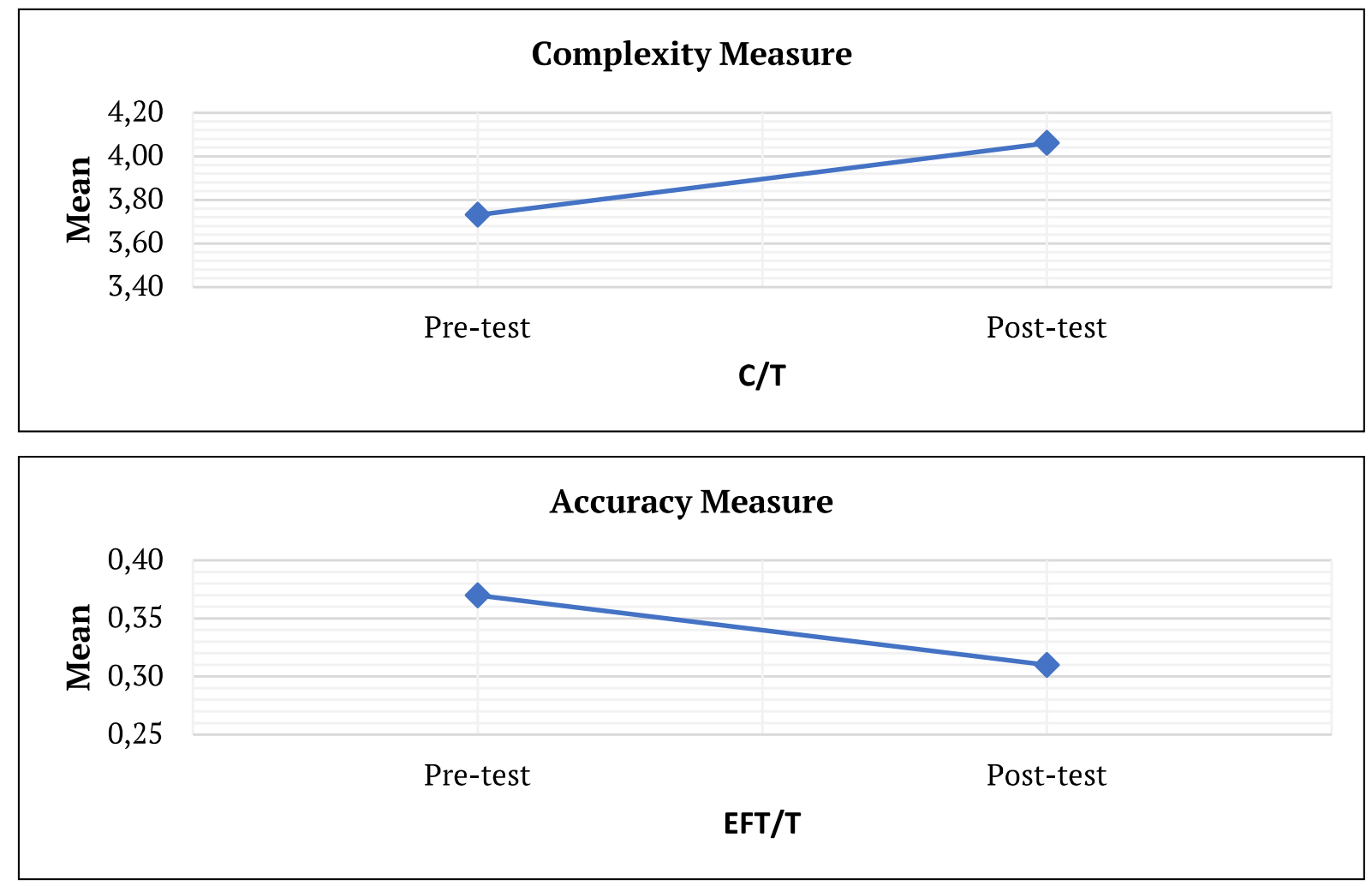


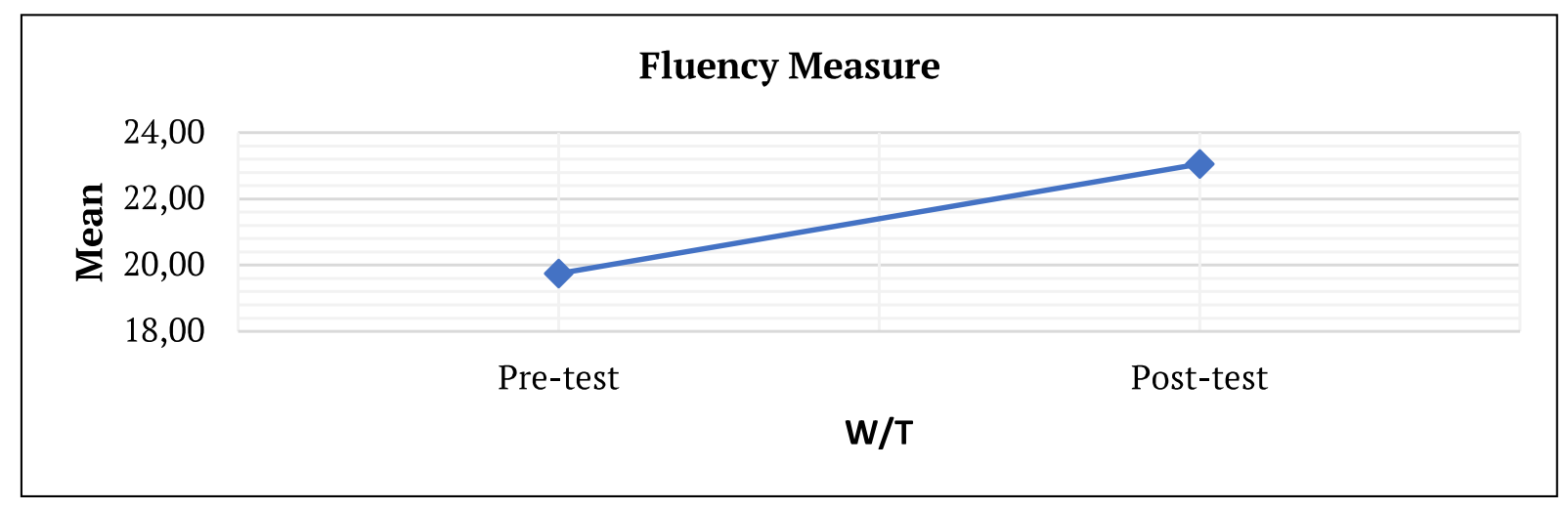

\section{Main Findings}

The first research question asked whether reflecting on positive self-disclosures helps improve EFL learners' production of complex language in writing as measured by $\mathrm{C} / \mathrm{T}$. The results indicated that the students' production of $\mathrm{C} / \mathrm{T}$ did not reach a statistically significant difference in the scores between the pre-test $(M=3.73$, $S D=1.63)$ and the post-test $(M=4.06, S D=1.56) ; t(14)=-.71, p>.10(p=.49)$ (see Table 2$)$.

\section{Table 2}

Paired-sample t-test for complexity in the students' pre- and post-tests

\begin{tabular}{|c|c|c|c|c|c|c|}
\hline & \multirow[t]{2}{*}{ Complexity } & \multicolumn{2}{|c|}{$\begin{array}{c}\text { Paired } \\
\text { Differences }\end{array}$} & \multirow[t]{2}{*}{$\mathbf{t}$} & \multirow[t]{2}{*}{ df } & \multirow{2}{*}{$\begin{array}{c}\text { Sig. } \\
\text { (2-tailed) }\end{array}$} \\
\hline & & Mean & SD & & & \\
\hline $\mathrm{C} / \mathrm{T}$ & & -.33 & 1.82 & -.71 & 14 & .49 \\
\hline
\end{tabular}

Note. ${ }^{*}$ < 10

The second research question asked whether reflecting on positive self-disclosures helps improve EFL learners' production of accurate language in writing as measured by EFT/T. The results showed that the participants' production of EFT/T did not reach a statistically significant difference in the scores between the pre-test $(M=$ $.37, S D=.20)$ and the post-test $(M=.31, S D=.32) ; t(14)=.87, p>.10(p=.39)$ (see Table 3).

Table 3

Paired-sample t-test for accuracy in the students' pre-and post-tests

\begin{tabular}{|c|c|c|c|c|c|c|}
\hline & \multirow[t]{2}{*}{ Accuracy } & \multicolumn{2}{|c|}{$\begin{array}{c}\text { Paired } \\
\text { Differences }\end{array}$} & \multirow[t]{2}{*}{$\mathbf{t}$} & \multirow[t]{2}{*}{ df } & \multirow{2}{*}{$\begin{array}{c}\text { Sig. } \\
\text { (2-tailed) }\end{array}$} \\
\hline & & Mean & SD & & & \\
\hline $\mathrm{EFT} / \mathrm{T}$ & & .06 & 28 & .87 & 14 & .39 \\
\hline
\end{tabular}

Note. ${ }^{*}$ $<.10$

The third research question asked whether reflecting on positive self-disclosures helps improve EFL learners' production of fluent language in writing as measured by W/T. The findings showed that the participants' production of W/T did not reach a statistically significant difference in the scores between the pre-test $(M=$ $19.75, S D=3.95)$ and the post-test $(M=23.06, S D=7.68) ; t(14)=-1.7, p>.10(p=.106)$ (see Table 4$)$.

Table 4

Paired-sample t-test for fluency in the students' pre- and post-tests

\begin{tabular}{|c|c|c|c|c|c|c|}
\hline & \multirow[t]{2}{*}{ Fluency } & \multicolumn{2}{|c|}{$\begin{array}{c}\text { Paired } \\
\text { Differences }\end{array}$} & \multirow[t]{2}{*}{$\mathbf{t}$} & \multirow[t]{2}{*}{ df } & \multirow{2}{*}{$\begin{array}{c}\text { Sig. } \\
\text { (2-tailed) }\end{array}$} \\
\hline & & Mean & SD & & & \\
\hline $\mathrm{W} / \mathrm{T}$ & & -3.30 & 7.4 & -1.7 & 14 & .106 \\
\hline
\end{tabular}

Note. ${ }^{*} p<.10$ 


\section{Discussion}

This study is the first to assess whether undergraduate learners' reflections on positive self-disclosures aided writing development in terms of CAF in the EFL classroom, especially in Morocco. Although one previous study (Serag, 2011) examined self-disclosure and writing, the author used a different research design and had dissimilar objectives from the current study. Hence, results from this manuscript are incomparable with those of Serag's study.

The participants were relatively homogeneous in their level of English proficiency before completing the six self-disclosure activities (i.e., the treatment). Although descriptive statistics revealed that the participants' production of complex and fluent language improved after the treatment, the main findings indicated that the learners' writing development did not reach a statistically significant difference in terms of complexity (C/T), accuracy (EFT/T), and fluency (W/T). With regard to complexity, although the participants' mean score on the post-test $(M=4.06)$ increased from the mean score on the pre-test $(M=3.73)$, the learners showed no significant development in $\mathrm{C} / \mathrm{T}$, indicating that simple and compound sentences were prominent in their pieces of writing. This conclusion supports the claim that writing about personal matters encourages the production of simple linguistic forms (Foster \& Skehan, 1996). Thus, the learners' use of complex sentences including one or more dependent clauses (i.e., T-unit) in writing was weak. As for accuracy, the students produced more errors when producing complex sentences throughout writing, and the descriptive statistics confirmed this result, as the test takers' mean score in EFT/T on the post-test $(M=.31)$ decreased from the mean score of the pre-test $(M=$ .37). With respect to fluency, the descriptive statistics showed that the learners' mean score in W/T on the posttest $(M=23.06)$ was higher than that of the pre-test $(M=19.75)$. However, the $t$-test was found to be statistically insignificant, suggesting that the participants' length of complex sentences was modest because of having a lower amount of vocabulary.

The absence of significant differences regarding the test takers' writing development reiterates that the CAF measures "do not operate in complete independence from each other, and that findings obtained by CAF measures depend crucially on the participants involved and on the context in which the data are collected" (Houssen \& Kuiken, 2009, p. 469). The participants did not show significant development in writing due to a number of factors.

First, the participants' inability to produce complex sentences might have been affected by the different task prompts that elicited differing performances. While the pre-test task was a narrative and persuasive piece of writing, the post-test task was an argumentative piece of writing. Perhaps the argumentative type of writing was more difficult than the narrative and persuasive type of writing. Second, the students' low grammar levels and the non-use of dictionaries during the writing process justify the breakdown in producing accurate language on the post-test. Although the study did not classify the errors made by the participants, the frequent mistakes identified in their writing were concerned with spelling, word choice, and tense use. The learners completed the writing topics outside the classroom, where they had enough time to consult dictionaries and grammar books to construct an accurate piece of writing. However, writing in an EFL context requires learning to express thoughts while simultaneously learning the target language; as such, "grammatical errors are unavoidable because of the cognitive demand of performing both tasks at the same time" (Liao, 2016, p. 77). Third, the learners' deficiency in using complex language without mistakes negatively affected their production of a higher number of words per T-unit in return, indicating that they need to enrich their language repertoire with vocabulary. Fourth, the students' academic learning experiences are the last factor that best explains the overall findings. First-year students were in the process of integrating into the university atmosphere after graduating from high school, and hence their encounter with writing for the first time outside the classroom was a new task that required skills that they might have not developed yet. For instance, teachers expect novice learners to produce simple language in their first academic year because they will study advanced grammar in the second year. Second-year students were in the process of studying the complex sentences during the implementation of this study. While participation in this research was an opportunity for these students to practice their language, they may have lacked the skill of transferring what they had learnt in the advanced grammar class to the writing pre- and post-tests. However, third-year students were beginning to write a research paper for the first time and were obliged to submit the theoretical part of their monographs to their supervisors before the end of the first semester to fulfil graduation requirements. These factors coupled with preparation for final examinations created frustration among the participants, who decided to devote less 
effort to complete the writing tasks, thereby displaying insufficient writing performance after they completed the self-disclosure topics.

As a final note, the main obstacle to assessing the role of writing activities in most departments of English in Morocco involved students' perceptions of writing as a boring and demanding activity and the belief that homework was not a course requirement. Although some professors assign writing activities, many students object to doing the task in or out of class. This perception explains the limited number of participants, whose decision to take part in this study should be understood as an act of kindness to help the researcher collect data and an opportunity to become familiar with the types of prompts that they may have in summative examinations. Being aware of the challenges affecting L2 writing research in higher education in Morocco explains the emergence of limitations relating to internal and external validity.

The first limitation was concerned with the low number of participants who took part in this investigation. Inclusion of a larger number of participants in the study could have yielded significant scores between the preand post-test. The second limitation involved the absence of examining the effects of extraneous variables, such as the participants' degree of motivation on writing development. Another methodological limitation was related to the unlimited time set for the participants to finish the writing activities. If time for completing writing tasks had been controlled, the analysis could have yielded different results and conclusions. The last limitation had to do with external validity. That is, conclusions could be drawn only about the target participants who participated in this study since EFL students' overall language abilities differ even within one grade level due to the non-use of placement tests to diagnose high school graduates' level of English proficiency when enrolling in most university English departments in Morocco (for further details, see Jebbour, 2019). Thus, the sample cannot be considered representative and may not provide generalizable findings for the total population of EFL learners in the same setting.

\section{Conclusion}

This study concluded that although descriptive statistics revealed that the EFL students showed relative development in $\mathrm{C} / \mathrm{T}$, and $\mathrm{W} / \mathrm{T}$ as well as a breakdown in EFT/T after they completed the six self-disclosure prompts, the main findings showed that the learners' writing production in terms of CAF did not reach a statistically significant difference level, indicating that the test takers' writing development did not improve after the treatment.

The current results suggest theoretical and practical implications for language educators, teachers, researchers, and learners. At the theoretical level, this study contributes to the debate over the role of self-disclosure activities in improving certain language components by providing empirical data from the EFL context of Morocco in an effort to enrich the theory of L2 writing pedagogy. At the practical level, this study may inform educational decisions about developing study programs that consider students' personal lives in language arts classes. Furthermore, the findings from this manuscript may inform teaching practices by providing language instructors with essential implications for encouraging students to use personal information with the aim to improve certain language components. First, for teachers whose students aim to continue their studies abroad, self-disclosure writing activities may function as a rehearsal strategy to support students' oral performance by talking about their personal experiences while engaging in friendly interaction with foreigners. Second, if teachers involved in language teaching are interested in helping their students produce simple language illustrated in independent clauses, self-disclosure topics may be meaningful for meeting this objective. Accordingly, the inclusion of self-disclosure prompts in a 'paragraph writing' course could be an effective choice in departments of English studies. Third, the increased numbers of errors in the learners' written output require composition teachers to include grammar activities (e.g., text conversion) in their classes and put consistent emphasis on the use of dictionaries to improve students' syntactic knowledge and minimise the production of less accurate language forms and words in the language production stage. Finally, participation in this study may increase the participants' awareness of the benefits of reflecting on self-disclosures through diaries or journals, which might give support to their language skills.

Future directions for research are necessary to enrich discussions about the effects of self-disclosure tasks on students' writing development in the language classroom. Accordingly, conducting an experimental study where 


\section{MOHSINE JEBBOUR}

participants complete self-disclosure and non-self-disclosure writing prompts is necessary. Such a study requires the use of the same task prompt for a pre- and post-test and a control group to better determine the effects of self-disclosure writing activities on writing development. Similarly, a longitudinal study can better increase understanding of the role of positive self-disclosures and their effect on students' language proficiency in the written mode because improving writing skills cannot be described based on completing only six self-disclosure topics in a relatively short period of time. Lastly, it would be interesting to carry out a study on students' selfdisclosures in relation to one or two measures maximum (e.g., accuracy and fluency), using other aspects of the measures, such as error-free clauses per clause and the number of clauses in a text, and errors with classification.

\section{Acknowledgment}

I would like to thank the participants for devoting time to participate in this study. I would also like to thank the anonymous reviewers and editor whose comments contributed to the development of the quality of this manuscript.

\section{References}

Antaki, C., Barnes, R., \& Leudar, I. (2005). Self-disclosure as a situated interactional practice. British Journal of Social Psychology, 44(2), 181-199. https://doi.org/10.1348/014466604x15733

Altman, I., \& Taylor, D. (1973). Social penetration: The development of interpersonal relationships. Holt, Rinehart \& Winston.

Barrot, J. S. (2018). Using the sociocognitive-transformative approach in writing classrooms: Effects on L2 learners' writing performance. Reading \& Writing Quarterly, 34(2), 187-201. https://doi.org/10.1080/105735 69.2017.1387631

Barrot, J., \& Gabinete, M. (2019). Complexity, accuracy, and fluency in the argumentative writing of ESL and EFL learners. In P. Jordens \& R. Leah (Eds.), International review of applied linguistics in language teaching (pp. 1-24). DeGruyter Mouton.

Bento, S. (1991). [Review of the book Learning and instruction: European research in an international context, Volume 2:2. Analysis of complex skills and complex knowledge domains, by H. Mandl, E. De Corte, S. N. Bennett \& H. F. Friedrich]. Computers \& Education, 17(2), 169-171.

Berman, J. (2001). Risky writing: Self-disclosure and self-transformation in the classroom. University of Massachusetts Press.

Bernard, J. (2010). Motivation in foreign language learning: The relationship between classroom activities, motivation, and outcomes in a university language-learning environment [Unpublished Master's thesis]. Carnegie Mellon University. http://repository.cmu.edu

Birhan, A. (2018). Effects of mastery learning instruction on engineering students' writing skills development and motivation. Journal of Language and Education, 4(4), 20-30. https://doi.org/10.17323/2411-7390-2018-4-4-20-30

Cayanus, J. L., \& Martin, M. M. (2016). Teacher self-disclosure. In P.L. Witt (Ed.), Handbook of communication science (vol: 16. Communication and Learning, pp. 241-258). DeGruyter Mouton.

Cayanus, J. L., Martin, M. M., \& Goodboy, A. K. (2009). The relationship between teacher self-disclosure and student motives to communicate. Communication Research Reports, 26(2), 105-113. https://doi. org/10.1080/08824090902861523

Derlega, V. J., Anderson, S., Winstead, B. A., \& Greene, K. (2010). Positive disclosure among college students: What do they talk about, to whom, and why? Journal of Positive Psychology, 6(2), 119-130. https://doi.org/10 $.1080 / 17439760.2010 .545430$

Derlega, V. J., \& Winstead, B. A., \& Greene, K. (2008). Self-disclosure and starting a close relationship. In S. Sprecher, A. Wenzel \& J. Harvey (Eds.), Handbook of relationship beginnings (pp. 153-174). Psychology Press.

Dörnyei, Z. (1994). Motivation and motivating in the foreign language classroom. Modern Language Journal, 78(3), 273-284. http://www.jstor.org/stable/330107?origin=JSTOR-pdf

Foster, P., \& Skehan, P. (1996). The influence of planning and task type on second language performance. Studies in Second Language Acquisition, 18(3), 299-323. https://doi.org/10.1017/S0272263100015047

Graham, S., Harris, K. R., \& Santangelo, T. (2015). Research-based writing practices and the common core: Meta-analysis and meta-synthesis. The Elementary School Journal, 115(4), 498-522. https://doi.org/10.1086/ 681964 
Guilloteaux, M. J., \& Dörnyei, Z. (2008). Motivating language learners: A classroom-oriented investigations of the effects of motivational strategies on student motivation. TESOL Quarterly, 42(1), 55-78. https://doi. org/10.1002/j.1545-7249.2008.tb00207.x

Hoadley-Maidment, E. (2000). From personal experience to reflective practitioner: Academic literacies and professional education. In M. Lea \& B. Stierer (Eds.), Student writing in higher education: New contexts (pp. 165-78). Society for Research into Higher Education \& Open University Press.

Housen, A., \& Kuiken, F. (2009). Complexity, accuracy, and fluency in second language acquisition. Applied Linguistics, 30(4), 461-473. https://doi.org/10.1093/applin/amp048

Iida, A. (2016). Poetic identity in second language writing: Exploring an EFL learner's study abroad experience. Eurasian Journal of Applied Linguistics, 2(1), 1-14. https://www.ejal.info/index.php/ejal/article/view/131

Jebbour, M. (2020). Developing a student self-disclosure measure: A pilot study. Journal of English Language Teaching and Linguistics, 5(1), 17-27. http://dx.doi.org/10.21462/jeltl.v5i1.374

Jebbour, M. (2019). English language teaching in Morocco: A focus on the English department. The Journal of North African Studies. https://doi.org/10.1080/13629387.2019.1681267

Jebbour, M. (2018). University students' perceptions of the effects of teacher self-disclosure in the English language classroom. Journal of English Language Teaching and Linguistics, 3(3), 275-285. http://dx.doi. org/10.21462/jeltl.v3i3.166

Jebbour, M., \& Mouaid, F. (2019). The impact of teacher self-disclosure on student participation in the university English language classroom. International Journal of Teaching and Learning in Higher Education, 31(3), 424436.

Jourard, S. (1971). The transparent self. Van Nostrand.

Komalasari, A. (2013). Employing experiential learning to teach writing for English as a foreign language learners through a reflection project. International Journal on Education, 1(1), 24-30.

Klingberg, T. (2010). Training and plasticity of working memory. Trends in Cognitive Sciences, 14, 317-324. https://doi.org/10.1016/j.tics.2010.05.002

Lam, R. (2015). Convergence and Divergence of Process and Portfolio Approaches to L2 Writing Instruction: Issues and Implications. RELC Journal, 46(3), 293-308. https://doi.org/10.1177/0033688215597119

Lannutti, P. J., \& Strauman, E. C. (2006). Classroom communication: The influence of instructor self-disclosure on student evaluations. Communication Quarterly 54(1), 89-99. https://doi.org/10.1080/01463370500270496

Larson-Hall, J. (2010). A guide to doing statistics in second language research using SPSS. Routledge.

Liao, C. (2016). Enhancing the grammatical accuracy of EFL writing by using an AWE-assisted process approach. System, 62, 77-92. https://doi.org/10.1016/j.system.2016.02.007

McDonough, K., \& Fuentes, C. G. (2015). The effect of writing task and task conditions on Colombian EFL learners' language use. TESL Canada Journal, 32(2), 67-79.

Moon, J. (2004). A handbook of reflective and experiential learning. Routledge Falmer.

Myers, S. (1998). Students' self-disclosure in the college classroom. Psychological Reports, 83(7), 1067-1070. https://doi.org/10.2466\%2Fpr0.1998.83.3.1067

Norris, J., \& Manchón, R. M. (2012). Investigating L2 writing development from multiple perspectives: Issues in theory and research. In R.M. Manchón (Ed.), L2 writing development: Multiple perspectives (pp. 221-244). de Gruyter Mouton.

Peng, J., \& Wang, Ch. (2018). Effect of the linguistic complexity of the input text on alignment, writing fluency, and writing accuracy in the continuation task. Language teaching Research, 00(0), 1-18. https://doi. org/10.1177/1362168818783341

Polio, C. (2001). Research methodology in second language writing: The case of text-based studies. T. Silva \& P. Matsuda. (Eds.), On second language writing (pp. 91-116). Erlbaum.

Polio, C., \& Park, J. H. (2016). Language development in second language writing. In R. M. Manchon' \& P. Matsuda (Eds.), Handbook of second and foreign language writing (pp. 287-306). Routledge.

Polio, C., \& Shea, M. C. (2014). An investigation into current measures of linguistic accuracy in second language writing research. Journal of Second Language Writing, 26, 10-27. https://doi.org/10.1016/J.JSLW.2014.09.003

Rosmawati (2014). Second language development dynamics: How dynamic systems theory accounts for issues in second language learning. The Australian Educational and Development Psychologist, 31(1), 66-80. https:// doi.org/10.1017/edp.2013.22

Serag, A. (2011). Self-disclosure in EFL writing by computers. In A. Stewart (Ed.), JALT2010 Conference Proceedings (pp. 551-564). JALT.

Skehan, P., \& Foster, P. (1997). Task type and task processing conditions as influences on foreign language performance. Language Teaching Research, 1(3), 185-211. https://doi.org/10.1177\%2F136216889700100302 


\section{MOHSINE JEBBOUR}

Stotsky, S. (1995). The uses and limitations of personal or personalized writing in writing theory, research, and instruction. Reading Research Quarterly, 30(4), 758-776. https://doi.org/10.2307/748197

van Geert, P., \& van Dijk, M. (2003). Ambiguity in child language: The problem of inter-observer reliability in ambiguous observation data. First Language, 23(3), 259-284. https://doi.org/10.1177/01427237030233001

Van Waes, L., \& Leijten, M. (2015). Fluency in writing: A multidimensional perspective on writing fluency applied to L1 and L2. Computers and Composition, 38, 79-95. https://doi.org/10.1016/j.compcom.2015.09.012

Wakefield, C.R. (2009). Self-disclosure and cohesion in the religious classroom [Unpublished Master's thesis]. Southern Utah University. https://www.suu.edu

West, R., \& Turner, L. (2010). Introducing communication theory: Analysis and application (4 $4^{\text {th }}$ ed.). McGraw Hill.

Wheeless, L. R., \& Grotz, J. (1976). Conceptualization and measurement of reported self- disclosure. Human Communication Research, 2(4), 338-346. https://doi.org/10.1111/j.1468-2958.1976.tb00494.x

Wolfe-Quintero, K., Inagaki, S., \& Kim, H. Y. (1998). Second language development in writing: Measures of fluency, accuracy, and complexity. University of Hawaii Press.

Zhang, S., Shi, Q., Tonelson, S., \& Robinson, J. (2009). Preservice and inservice teachers' perceptions of appropriateness of teacher self-disclosure. Teaching and Teacher Education, 25(8), 1117-1124. http://dx.doi. org/10.1016/j.tate.2008.07.011 


\section{Appendix A}

\section{A writing post-test sample}

It is very necessary for English students to get a close and a direct contact with an English speaking country like England, Australia, and the United States of America. Because of that, the university must organize a study trip to one of those countries. The main reason that makes this trip very important is that students will be face to face with the English culture. There is no way to learn a language without understanding its culture. By doing so, students will have a better awareness and consciousness about what they're thinking, saying, and writing. Another good reason that makes the study trip a great idea is that students will use it to practice their language skills, especially the skills of understanding and speaking. Additionally, it will make them curious about both the culture and the language, which will make them highly motivated, passionate, and excited for their education. A study trip is always a positive thing to do. It has a lot of benefits that will make students do better in their studies, also their job career. 


\section{MOHSINE JEBBOUR}

\section{Appendix B}

\section{T-units in the writing post-test sample}

1. The main reason that makes this trip very important (DC) is that students will be face to face with the English culture (IC).

2. Students will have a better awareness and consciousness (IC) about what they're thinking, saying and writing (DC).

3. It will make them curious about both the culture and the language (IC), which will make them highly motivated, passionate, and excited for their education (DC).

4. It has a lot of benefits (IC) that will make students do better in their studies, also job career (DC).

5. Another good reason that makes the study trip a great idea (DC) is that students will use it to practice their language skills (IC).

\section{Errors in the writing post-test sample}

1. consciousness about

2. excited for

3. also their job career

Calculation of CAF measures of the writing post-test sample

\begin{tabular}{lc}
\hline \multicolumn{1}{c}{ Parameter and calculation } & Coding \\
\hline $\mathrm{C} / \mathrm{T}=14 / 5$ & 2.8 \\
$\mathrm{EFT} / \mathrm{T}=2 / 5$ & 0.4 \\
$\mathrm{~W} / \mathrm{T}=100 / 5$ & 20 \\
\hline
\end{tabular}

